\title{
Determination of Seventeen $s$-Triazine Herbicides and Derivatives by High-Pressure Liquid Chromatography
}

\author{
Paul Beilstein, Alasdair M. Cook,* and Ralf Hütter
}

Mixtures of simazine, atrazine, ametryne, prometryne, deethylsimazine, deethylatrazine, hydroxysimazine, hydoxyatrazine, hydoxyprometryne, $N$-ethyl- and $N$-isopropylammeline, $N$-ethyl- and $N$-isopropylammelide, melamine, ammeline, ammelide, and cyanuric acid in aqueous solution were separated and determined in a single analysis with a detection limit of 30-400 pmol. The $s$-triazines were detected by a UV detector after elution from a reversed-phase high-pressure liquid chromatography column using a phosphate buffer-methanol gradient at $2^{\circ} \mathrm{C}$.

The $s$-triazine herbicides are widely used, accounting for $28 \%$ of herbicide manufacture in 1974 (Kühle, 1976), and $s$-triazines have many other industrial uses [e.g., Cook and Hütter (1981a)]. However, no single method is available for the routine identification and quantification of these compounds, especially the more polar derivatives like ammeline, ammelide, and their $\mathrm{N}$-alkylated derivatives. The available techniques all apply only to limited ranges of compounds. Paper chromatography and thin-layer chromatography require many solvent systems for the desired separations and offer poor and time-consuming quantification [reviews by Fishbein $(1970,1975)$; see also Loos and Kearney (1978)]. Gas chromatography has been used extensively, but derivatization is essential for many compounds and there seems to be no universal derivatizing agent; furthermore, derivatization is seldom quantitative, and several columns are required to cover the whole range of compounds (Fishbein, 1970, 1975; Lusby and Kearney, 1978; Muir and Baker, 1978; Stoks and Schwartz, 1979; Muir, 1980). Low-pressure column chromatography, which has poor separative properties and is time consuming, has been used occasionally (Plaisted and Thornton, 1964). High-pressure liquid chromatography (HPLC) of $s$-triazines overcomes many difficulties arising from low volatility, low solubility, and chemical inertness. Thus, e.g., Smolkovâ and Pacákovâ (1978) separated 19 s-triazine herbicides on a CN-bonded silica column [see also Lawrence and Turton (1978)]. Lawrence and Leduc (1978), Ramsteiner and Hörmann (1979), and Muir (1980) showed partial separation of $N$-alkylammelines and five "hydroxyparents" (hydroxysimazine, hydroxyatrazine, hydroxyprometryne, etc.) on silica columns. Demian et

Mikrobiologisches Institut, Eidgenössische Technische Hochschule, ETH-Zentrum, CH-8092 Zürich, Switzerland. al. (1979) used a reversed-phase column to determine hydroxyparents. Each of these methods covers only limited ranges of compounds.

We report here a simple method to identify and quantify chloro- and (methylthio)-s-triazine herbicides, dealkylatrazines, hydroxyparents, $N$-alkylammelines, $N$-alkylammelides, melamine, ammeline, ammelide, and cyanuric acid in aqueous solutions by reversed-phase HPLC of underivatized samples.

\section{EXPERIMENTAL SECTION}

Apparatus. HPLC was done using jacketed stainless steel analytical columns $(25 \mathrm{~cm} \times 4.6 \mathrm{~mm}$ inner diameter) containing a reversed-phase packing of $5-\mu \mathrm{m}$ mean particle diameter (LiChrosorb RP-18; Merck, Darmstadt, FRG). The mobile phase was delivered through a dynamic mixer (Altex, Berkeley, CA) by two pumps (Altex Model 110) which were controlled by a gradient programmer (Altex Model 420), and samples were applied to the column by using a high-pressure sample injector with pneumatic actuator (Model 7010/70-01; Rheodyne, Berkeley, CA) connected to an automatic sampler (ASI 45; Kontron, Zürich, Switzerland). The sample loop of the injector was normally $20 \mu \mathrm{L}$. The eluate from the column passed through a UV detector (Uvikon LCD 725; Kontron) coupled to an integrator with printer/plotter (C-R1A; Shimadzu, Kyoto, Japan). The HPLC column was maintained at $2^{\circ} \mathrm{C}$ by passing cooling fluid from a cryostat through the jacket.

Mass spectra were obtained with a Hitachi Perkin-Elmer RMU-6 mass spectrometer by using direct probe insertion and electron impact ionization at $70 \mathrm{eV}$. UV spectra were obtained by using a Uvikon 820 spectrophotometer (Kontron).

Chemicals. The $s$-triazines used, their abbreviations, sources, and Chemical Abstracts Service Registy Numbers are given in Table I. The identity of each triazine was 
Table I. $s$-Triazines

\begin{tabular}{|c|c|c|c|}
\hline trivial name & $\begin{array}{l}\text { abbre- } \\
\text { viation }\end{array}$ & registry no. ${ }^{a}$ & purity $^{b}$ \\
\hline $\begin{array}{l}\text { simazine }^{c} \\
\text { atrazine }^{c} \\
\text { ametryne }^{c} \\
\text { prometryne }^{c} \\
\text { hydroxysimazine } \\
\text { hydroxyatrazine }^{c} \\
\text { hydroxyprometryne } \\
\text { deethylsimazine }^{c} \\
\text { deethylatrazine }^{c} \\
N \text {-ethylammeline } \\
N \text {-isopropylammeline } \\
N \text {-ethylammelide } \\
N \text {-isopropylammelide } \\
\text { melamine } \\
\text { ammeline }^{c} \\
\text { ammelide } \\
\text { cyanuric acid }^{c}, d\end{array}$ & $\begin{array}{l}\text { SI } \\
\text { AT } \\
\text { AM } \\
\text { PR } \\
\text { OHSI } \\
\text { OHAT } \\
\text { OHPR } \\
\text { CEAT } \\
\text { CIAT } \\
\text { NEN } \\
\text { NIN } \\
\text { NED } \\
\text { NID } \\
\text { MN } \\
\text { AN } \\
\text { AD } \\
\text { CN }\end{array}$ & $\begin{array}{l}122-34-9 \\
1912-24-9 \\
834-12-8 \\
7287-19-6 \\
2599-11-3 \\
2163-68-0 \\
7374-53-0 \\
1007-28-9 \\
6190-65-4 \\
7313-54-4 \\
19988-24-0 \\
2630-10-6 \\
35200-63-6 \\
108-78-1 \\
645-92-1 \\
645-93-2 \\
108-80-5\end{array}$ & $\begin{array}{l}98 \\
99 \\
99 \\
99 \\
98 \\
99 \\
99 \\
88 \\
98 \\
98 \\
98 \\
94 \\
98 \\
98 \\
98 \\
99 \\
99\end{array}$ \\
\hline \multicolumn{4}{|c|}{$\begin{array}{l}{ }^{a} \text { Chemical Abstracts Service Registry Number. }{ }^{b} \text { Esti- } \\
\text { nated from elementary analysis. c Obtained from Ciba- } \\
\text { Geigy, Basel, Switzerland. d Purchased from Fluka, } \\
\text { 3uchs, Switzerland. }\end{array}$} \\
\hline
\end{tabular}

confirmed by mass spectrometry. The spectra of SI [e.g., Jörg et al. (1966)], AT and PR (Safe and Hutzinger, 1973), CEAT (Ross and Tweedy, 1970), and OHSI, OHAT, OHPR, NEN, NIN, NED, NID, and AN (Plashko, 1972) agree with published data. For the following mass spectra, which followed the anticipated pattern, the two most intense ions are presented for every 14 mass units above $m / z$ 34 (rel intensity $\geq 1$ ): AM, 41 (8), 43 (18), 57 (7), 58 (19), 68 (16), 69 (13), 83 (5), 85 (5), 96 (8), 98.5 (11), $106(5), 111$ (5), $122(6), 123(4), 138(8), 142(5), 155(10), 157(7), 169$ (7), 170 (23), 184 (14), 185 (25), 196 (2), 199 (3), 212 (60), $213(8), 227\left(\mathrm{M}^{+}, 100\right), 228(15) ; \mathrm{CIAT}, 42(9), 43(22), 53$ (2), $58(20), 68(16), 69(22), 79(5), 83(3), 94(7), 95(2)$, 104 (15), 110 (8), 130 (6), 136 (3), 145 (23), 146 (2), 147 (7), 172 (100), 173 (9), $174(36), 187\left(\mathrm{M}^{+}, 38\right), 189$ (13); MN, $42(6), 43(35), 63(1), 68(8), 83(5), 85(19), 126\left(\mathrm{M}^{+}, 100\right)$, 127 (7); AD, 42 (42), 43 (50), 56 (2), 57 (2), 69 (21), 70 (5), 85 (65), $86(3), 95(1), 100(1), 111(1), 112(2), 128\left(\mathrm{M}^{+}\right.$, 100), 129 (7); CN, 43 (52), 44 (61), 69 (1), 70 (14), 86 (18), $87(3), 91(1), 129\left(\mathbf{M}^{+}, 100\right), 130(5)$.

The purity of the $s$-triazines was estimated by elementary analysis (Table I), and most compounds were better than $98 \%$ pure, and all were better than $88 \%$.
The following stock solutions of $s$-triazines were prepared. Either $2 \mathrm{mM}$ SI, $30 \mathrm{mM}$ AT, $30 \mathrm{mM}$ AM, $30 \mathrm{mM}$ $\mathrm{PR}, 30 \mathrm{mM}$ CEAT, or $30 \mathrm{mM}$ CIAT was dissolved in ethanol. Either $30 \mathrm{mM}$ OHSI, $30 \mathrm{mM}$ OHAT, $30 \mathrm{mM}$ OHPR, $10 \mathrm{mM}$ NEN, $10 \mathrm{mM}$ NIN, $10 \mathrm{mM}$ NED, $10 \mathrm{mM}$ $\mathrm{NID}$, or $6 \mathrm{mM}$ AN was dissolved in $0.1 \mathrm{M} \mathrm{HCl}$. AD (10 $\mathrm{mM}$ ) was dissolved in $0.1 \mathrm{M} \mathrm{NaOH}$. Either $10 \mathrm{mM}$ MN or $15 \mathrm{mM}$ CN was dissolved in water. The solutions were stable in filter-sterilized solutions for several months at room temperature. Standard curves of peak height (or area) vs. concentration were obtained by using dilutions of stock solutions in $0.1 \mathrm{M}$ potassium phosphate buffer, $\mathrm{pH} 6.7$; addition of acid or base was neutralized by an equal volume of equimolar base or acid. This method of bringing a $s$-triazine into solution in biological media sometimes led to higher solubilities than could be obtained by direct dissolution; thus NIN and NEN had solubilities of $2 \mathrm{mM}$ (Table II), values values that were above the data (0.3-0.5 $\mathrm{mM}$ ) given by Ramsteiner and Hörmann (1979).

Glass double-distilled water was used throughout, and the mobile phase for HPLC was prepared by using water that had been passed through a reversed-phase column (Lobar RP-8; Merck) to eliminate material that otherwise caused ghost peaks on development of the methanol gradient. The methanol used for HPLC was LiChrosolv quality (Merck). The other chemicals used were of the highest purity available commercially.

Sample Preparation. Samples from bacterial or fungal cultures were centrifuged $\left(23000 \mathrm{~g}\right.$ for $20 \mathrm{~min}$ at $4{ }^{\circ} \mathrm{C}$ ) or filtered $(0.45-\mu \mathrm{m}$ pore diameter) before chromatography. Samples from enzyme assays were treated with perchloric acid ( $0.5 \mathrm{M}$ final concentration) and the precipitated protein was removed by centrifugation $(23000 \mathrm{~g}$ for $20 \mathrm{~min}$ at $4^{\circ} \mathrm{C}$ ). The supernatant fluid was neutralized with $1 \mathrm{M}$ $\mathrm{KOH}$, and the precipitate of $\mathrm{KClO}_{4}$ was removed by centrifugation $\left(23000 \mathrm{~g}\right.$ for $20 \mathrm{~min}$ at $4^{\circ} \mathrm{C}$ ) before analysis of the supernatant fluid. Samples to be stored were frozen to avoid biodegradation of the $s$-triazines. Care then had to be exercised to prevent precipitation of the $s$-triazines, which dissolved poorly or not at all on thawing the sample [see following paper (Cook and Hütter, 1981b)].

Samples of untreated waste water from $s$-triazine synthesis were neutralized before analysis: if a compound of interest was present at low concentration, the sample was neutralized at $0^{\circ} \mathrm{C}$ and the precipitate removed by filtration; otherwise the waste water was diluted 1:10 with

Table II. Analytical Parameters for the Quantitative Determination of $s$-Triazines in HPLC Analysis

\begin{tabular}{|c|c|c|c|c|c|c|}
\hline $\operatorname{compd}^{a}$ & $k^{\prime b}$ & $\mathrm{SD}^{c}$ of $k^{\prime}$ & $\begin{array}{l}\text { upper limit } \\
\text { of linear } \\
\text { range, mM }\end{array}$ & $\begin{array}{c}\text { minimal } \\
\text { detectable } \\
\text { amount, pmol }\end{array}$ & \multicolumn{2}{|c|}{$\begin{array}{l}\text { solubility in water } \\
\text { (approximate), } \mathrm{mM}\end{array}$} \\
\hline SI & 5.61 & 0.028 & 2.0 & $130^{d}$ & & $0.025^{e}$ \\
\hline $\mathrm{AT}$ & 6.23 & 0.031 & 0.48 & 90 & 0.5 & $0.153^{e}$ \\
\hline$A M$ & 7.53 & 0.038 & 1.2 & 400 & $>1.2$ & $0.814^{e}$ \\
\hline PR & 8.99 & 0.043 & 0.24 & 60 & 0.24 & $0.199^{e}$ \\
\hline OHSI & 4.37 & 0.017 & 0.03 & 60 & 0.15 & \\
\hline OHAT & 4.72 & 0.021 & 0.06 & $40^{d}$ & 0.24 & \\
\hline OHPR & 5,42 & 0.027 & 0.30 & 170 & 0.4 & \\
\hline CEAT & 4.72 & 0.020 & $>1.2$ & 30 & $\sim 1.2$ & \\
\hline CIAT & 4.98 & 0.024 & 1.2 & 30 & 2.0 & \\
\hline $\mathrm{NEN}$ & 3.73 & 0.027 & 0.8 & 33 & $>2.0$ & \\
\hline NIN & 4.28 & 0.021 & 0.4 & 410 & $>2.0$ & \\
\hline NED & 3.23 & 0.028 & 1.0 & 18 & $>1.0$ & \\
\hline NID & 3.87 & 0.029 & 1.0 & 210 & $>1.0$ & \\
\hline $\mathrm{MN}$ & 2.90 & 0.009 & 0.6 & 320 & 10 & \\
\hline AN & 1.01 & 0.004 & 0.6 & 40 & 0.6 & \\
\hline $\mathrm{AD}$ & 0.74 & 0.003 & 0.6 & 16 & 0.6 & \\
\hline $\mathrm{CN}$ & 1.21 & 0.014 & 0.9 & 240 & 23 & \\
\hline
\end{tabular}

$a$ See Table I for abbreviations. ${ }^{b}$ Capacity ratio (Engelhardt, 1977). $c$ Standard deviation of capacity ratio. $d$ Detection wavelength $240 \mathrm{~nm}$. ${ }^{\circ}$ Data from Esser et al. (1975). 


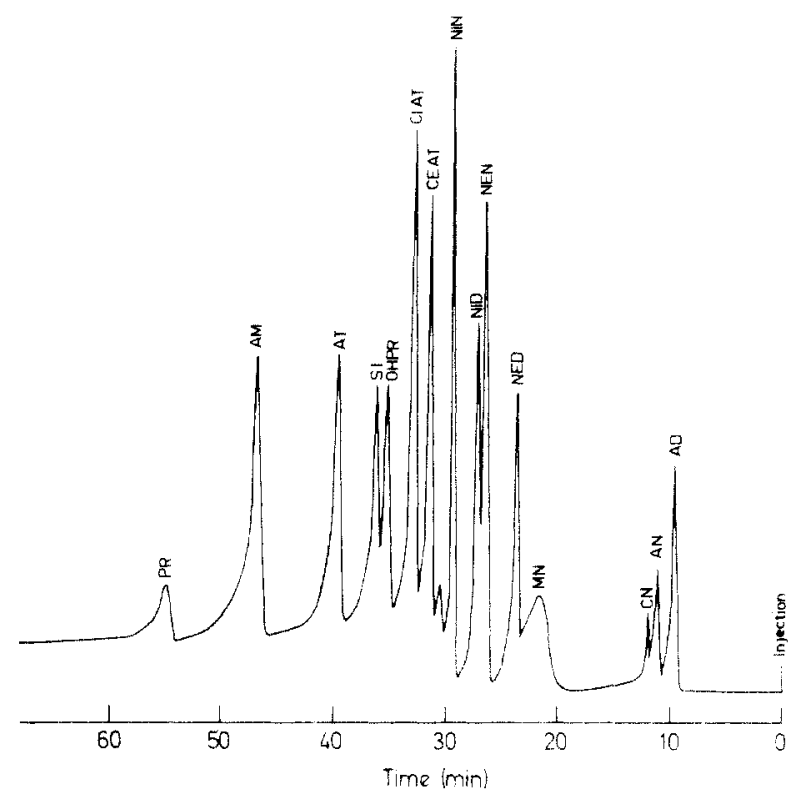

Figure 1. Typical chromatogram of an $s$-triazine mixture. The column used was specified under Experimental Section. The base line is not constant because of the higher absorption of methanol in the second solvent. The peak between NIN and CEAT is an impurity in water. For abbreviations see Table I.

water (to retain all compounds in solution) and neutralized.

Assay Procedure. The filtered, degassed mobile phase was maintained at a flow rate of $0.5 \mathrm{~mL} / \mathrm{min}$. The cooled column was equilibrated with $100 \mathrm{mM}$ potassium phosphate buffer, $\mathrm{pH}$ 6.7. A sample (routinely $20 \mu \mathrm{L}$ ) was injected on to the column, and after $10 \mathrm{~min}$ the linear gradient (20-min duration) was started by addition of the second solvent $[70 \%(\mathrm{v} / \mathrm{v})$ methanol in $10 \mathrm{mM}$ potassium phosphate, $\mathrm{pH}$ 6.7]: at 30 min after sample injection, only the second solvent was being used. The chromatogram was complete in $60 \mathrm{~min}$, at which time the gradient was reversed (5-min duration), and $75 \mathrm{~min}$ after injection the starting conditions had been reestablished. The detector was routinely set at $220 \mathrm{~nm}$ and a bandwidth of $8 \mathrm{~nm}$. Peaks were tentatively identified by cochromatography with authentic material.

\section{RESULTS AND DISCUSSION}

The major problem with the existing methods for analysis of $s$-triazines is the narrow range of compounds determined (see the introduction). The method described here overcomes that problem (Figure 1). Standard curves of peak height or peak area vs. concentration of $s$-triazine were linear (correlation coefficient $>0.99$ ) over defined ranges (Table II) for all compounds. There is no problem with unstable derivatives which complicate the quantification of some gas chromatographic techniques. On the other hand, as many $s$-triazines are now subject to rapid biodegradation (Cook and Hütter, 1981a), prepared samples may not be left for long periods (e.g., overnight) or growth may occur.

The short wavelength of the $s$-triazine absorption maxima led us to choose methanol for the gradient elution of melamine and the alkylated $s$-triazines. The buffer concentration in the second solvent was low because of low solubility of potassium phosphate in methanol. The wavelength routinely used in the detector was $220 \mathrm{~nm}$, but if particular compounds were under study, higher sensitivity could be achieved by adjusting the wavelength (cf. Table III). The sensitivity could also be increased by using a larger sample loop or preconcentrating the sample.

The simplest gradient elution is shown in Figure 1 (see
Table III. Ultraviolet Spectra of $s$-Triazines

\begin{tabular}{|c|c|c|c|c|c|c|}
\hline \multirow[b]{2}{*}{$\operatorname{compd}^{a}$} & \multicolumn{2}{|c|}{$\begin{array}{r}\text { dissolved in } \\
0.1 \mathrm{M} \mathrm{HCl}\end{array}$} & \multicolumn{2}{|c|}{$\begin{array}{c}\text { dissolved in } 0.1 \\
\text { M phosphate } \\
\text { buffer, pH } 7.0\end{array}$} & \multicolumn{2}{|c|}{$\begin{array}{l}\text { dissolved in } \\
0.1 \mathrm{M} \mathrm{NaOH}\end{array}$} \\
\hline & $\lambda_{\max }$ & $\begin{array}{l}\log \\
\epsilon_{\max }\end{array}$ & $\lambda_{\max }$ & $\epsilon_{\max }$ & $\overline{\lambda_{\max }}$ & $\begin{array}{c}\log \\
\epsilon_{\max }\end{array}$ \\
\hline SI & 221 & 4.41 & 221 & 4.53 & 223 & 4.58 \\
\hline $\mathrm{AT}$ & 222 & 4.41 & 221 & 4.36 & 223 & 4.46 \\
\hline $\mathrm{AM}$ & 223 & 4.31 & 222 & 4.59 & 224 & 4.54 \\
\hline $\mathrm{PR}$ & 223 & 4.40 & 203 & 4.50 & 226 & 4.40 \\
\hline OHSI & 205 & 4.55 & 214 & 4.31 & 222 & 4.31 \\
\hline OHAT & 206 & 4.52 & 216 & 4.34 & 222 & 4.24 \\
\hline OHPR & 205 & 4.48 & 215 & 4.29 & 222 & 4.28 \\
\hline CEAT & 214 & 4.55 & 213 & 4.64 & 218 & 4.94 \\
\hline CIAT & 236 & 4.44 & 215 & 4.64 & 220 & 4.39 \\
\hline NEN & 235 & 4.36 & 206 & 4.34 & 233 & 4.51 \\
\hline NIN & 236 & 4.35 & 208 & 4.54 & 233 & 4.48 \\
\hline NED & 204 & 4.49 & 225 & 4.33 & 227 & 4.61 \\
\hline NID & 203 & 4.57 & 226 & 4.32 & 227 & 4.59 \\
\hline $\mathrm{MN}$ & 209 & 4.55 & 205 & 4.71 & 234 & 4.37 \\
\hline AN & 229 & 4.31 & 213 & 3.97 & 234 & 4.60 \\
\hline $\mathrm{AD}$ & 201 & 4.12 & 221 & 4.03 & 230 & 4.42 \\
\hline $\mathrm{CN}$ & 214 & 3.38 & 214 & 4.00 & 213 & 4.64 \\
\hline
\end{tabular}

a See Table I for abbreviations.

Table IV. Retention Behavior of $\mathrm{AD}, \mathrm{AN}$, and $\mathrm{CN}$ at Different Column Temperatures

\begin{tabular}{cccc}
\hline \multirow{2}{*}{${ }^{\circ} \mathrm{C} p$} & \multicolumn{3}{c}{ capacity ratio $\left(k^{\prime}\right)$} \\
\cline { 2 - 4 } & $\mathrm{AD}$ & $\mathrm{AN}$ & $\mathrm{CN}$ \\
\hline 2 & 0.71 & 1.01 & 1.24 \\
10 & 0.57 & 0.80 & 0.92 \\
20 & 0.34 & 0.53 & 0.64 \\
30 & 0.27 & 0.43 & 0.43 \\
60 & 0.11 & 0.18 & 0.18
\end{tabular}

also Table II). Incomplete separations can be improved by the introduction of a stepped gradient. Not all compounds mentioned in Table I are shown in Figure 1. Hydroxysimazine and hydroxyatrazine are sparingly soluble and would be scarcely visible on this scale. There is, however, no inherent problem with these compounds as the method has a detection limit of about $40 \mathrm{pmol}$ (Table II).

The most difficult separation to achieve involved $\mathrm{CN}$, $\mathrm{AN}$, and $\mathrm{AD}$. CN was not eluted from an anion-exchange resin (Partisil SAX; Whatman, Clifton, NJ), and no separtion was observed on an $\mathrm{NH}_{2}$-modified stationary phase with mobile phases of $\mathrm{pH} 3-8.5$, so we concentrated on the reversed-phase packings, knowing that other $s$-triazine herbicide derivatives could be separated on them (Demian et al., 1979). RP-8 material gave poor separation of CN, $\mathrm{AD}$, and $\mathrm{AN}$, and this was not improved by ion-pair chromatography with $5 \mathrm{mM}$ tetrabutylammonium chloride in $0.1 \mathrm{M}$ borax, $\mathrm{pH} 8.5$, but $\mathrm{RP}-18$ material gave more promising results. Different RP-18 packing materials gave different but reproducible elution orders for $\mathrm{CN}, \mathrm{AD}$, and $\mathrm{AN}$, and we chose LiChrosorb to allow the best separation of the intermediates in the degradation pathway under study (Cook and Hütter, 1981a). The $\mathrm{pH}$ was chosen to give moderately strong UV absorption of all $s$-triazines studied (Table III), and the wavelength of the $s$-triazine absorption maxima committed us to phosphate buffer. The best separation of $\mathrm{CN}, \mathrm{AN}$, and $\mathrm{AD}$ at $25^{\circ} \mathrm{C}$ was at a buffer concentration of $100 \mathrm{mM}$, but separation was satisfactory only after reducing the temperature to $2{ }^{\circ} \mathrm{C}$ (Table IV). This temperature caused an increased viscosity, and the flow rate used $(0.5 \mathrm{~mL} / \mathrm{min})$ gave a maximum pressure of about $20 \mathrm{MPa}$. About 30000 theoretical plates $/ \mathrm{m}$ were necessary to obtain the required resolution, and we found columns packed in this laboratory to be as 
good as many supplied commercially.

Our research has been limited largely to whole-cell and enzyme work. We were able, however, to identify, e.g., CN and $\mathrm{AD}$ in untreated wastes from the manufacture of $s$ triazine herbicides. The tentative identification by cochromatography was supported by the UV spectrum of the eluted material. We combine such identification with isolation of the unknown for identification by mass spectrometry (Cook and Hütter, 1981b). Not all assays require that gradient elution be used, and in the following paper (Cook and Hütter, 1981b) frequent use was made of isocratic analyses.

This is the first report of the separation of $\mathrm{CN}, \mathrm{AD}, \mathrm{AN}$, MN, NED, NID, CEAT, and CIAT by HPLC. The method is simple and quantitative and allows rapid analysis of $s$-triazine herbicides and nonconjugated derivatives on a single column.

\section{ACKNOWLEDGMENT}

We thank J. Seibl, Laboratorium für Organische Chemie, Eidenössische Technische Hochschule, Zürich, for obtaining the mass spectra.

\section{LITERATURE CITED}

Cook, A. M.; Hütter, R. In "Microbial Degradation of Xenobiotics and Recalcitrant Compounds"; Leisinger, Th.; Cook, A. M.; Nüesch, J.; Hütter, R., Eds.; Academic Press: London, 1981a, in press.

Cook, A. M.; Hütter, R. J. Agric. Food Chem. 1981b, following paper in this issue.

Demian, B. A.; Borbely, V.; Kerek, F.; Bader, B.; Cirstea, M.; Dragusin, E. Rev. Chim. (Bucharest) 1979, 30, 281.

Engelhardt, H. "Hochdruck-Flüssigkeits-Chromatographie", 2nd ed.; Springer: Berlin, 1977.

Esser, H. O.; Dupuis, G.; Ebert, E.; Marco, G. J.; Vogel, C. In "Herbicides: Chemistry, Degradation and Mode of Action", 2nd ed.; Kearney, P. C.; Kaufman, D. D., Eds.; Marcel Dekker: New York, 1975; Vol. I, Chapter 2.

Fishbein, L. Chromatogr. Rev. 1970, 12, 167-238.

Fishbein, L. "Chromatography of Environmental Hazards"; Elsevier: Amsterdam, 1975; Vol. III, Chapter 17.

Jörg, J.; Houriet, R.; Spiteller, G. Monatsh. Chem. 1966, 97, 1064-1087.

Kühle, E. In "Ullmanns Encyklopädie der technischen Chemie", 4th ed.; Bartholomê, E.; Biekert, E.; Hellmann, H.; Ley, H.; Weigert, W. M., Eds.; Verlag Chemie: Weinheim, 1976; Vol. XII, p 614.

Lawrence, J. F.; Leduc, R. Anal. Chem. 1978, 50, 1161-1164.

Lawrence, J. F.; Turton, D. J. Chromatogr. 1978, 159, 207-226.

Loos, M. A.; Kearney, P. C. J. Chromatogr. Sci. 1978, 16, 86-89.

Lusby, W. R.; Kearney, P. C. J. Agric. Food Chem. 1978, 26, 635-638.

Muir, D. C. G. J. Agric. Food Chem. 1980, 28, 714-719.

Muir, D. C. G.; Baker, B. E. J. Agric. Food Chem. 1978, 26, 420-424.

Plaisted, P. H.; Thornton, M. L. Contrib. Boyce Thompson Inst. 1964, 22, 399-403.

Plashko, B. E. Ph.D. Dissertation, North Dakota State University, Fargo, ND, 1972.

Ramsteiner, K. A.; Hörmann, W. D. J. Agric. Food Chem. 1979, 27, 934-938.

Ross, J. A.; Tweedy, B. G. Org. Mass Spectrom. 1970, 3, 219-229.

Safe, S.; Hutzinger, O. "Mass Spectrometry of Pesticides and Pollutants"; Chemical Rubber Co.: Cleveland, $\mathrm{OH}, 1973$; Chapter 18.

Smolkovâ, E.; Pacákovâ, V. Chromatographia 1978, 11, 698-702.

Stoks, P. G.; Schwartz, A. W. J. Chromatogr. 1979, 168, 455-460. 